\title{
Suggestions to authors
}

\author{
Robert B. Daroff, MD; Lewis P. Rowland, MD; and Carol Scism
}

This journal transmits information from writers to readers. If authors keep readers in mind, they will more lucidly convey their ideas.

Competition for the limited space in Neurology is intense; authors who write clearly and directly are more likely to be successful in that competition.

Our message is simple: Write simply. Avoid jargon. Be certain your words express your ideas.

Brief suggestions follow:

1. Keep it short.

\section{Title of Paper}

2. Do not use the ambiguous word "deficit."

\section{Key Words}

On the title page, include "key words" for reference retrieval.

\section{Abstract}

1. The abstract should not exceed 150 words. Shorter is better.

2. Avoid statistical details; words suffice to carry your message.

3. Avoid sentences such as, "The implications are described." The Abstract should be meaningful by itself; it should not be a teaser.

4. In general, do not use abbreviations.

\section{General Suggestions}

1. Adhere strictly to the particular style of our journal, which is described in the Information for Authors in this issue of Neurology. To be sure that you recognize changes in the Information, please check a current issue. A manuscript submitted in the wrong style is insulting to the journal editors and may negatively prejudice reviewers and editors about its scientific worth. Using an incorrect reference style conveys the impression that the paper was previously rejected by another journal and the style wasn't changed for the resubmission; this, particularly, may cause an editor to be negatively disposed.

2. Edit your paper carefully to eliminate spelling, punctuation, and grammatical errors. After you type the "final" draft, force yourself to edit it one more time. Reviewers are irritated by poorly written manuscripts. An irritated reviewer may feel negatively about even a scientifically worthy manuscript.

3 . Scrupulously check the accuracy of your references. It is a disservice to readers to provide incorrect citations.

4. It is not the role of the editor's office or publisher to rewrite poorly written manuscripts; that responsibility rests entirely with the authors. Those who have difficulty writing scientific English should have a proficient colleague write the paper or should seek out the services of a professional editor who does this for a fee. (We can provide names and addresses.)

5. Organize your paper to answer the four main questions the reviewer and reader want answered:

- What did you set out to do and why? Introduction.

- How did you do it? Methods.

- What did you learn? Results.

- What does it mean and how does it relate to what else is known? Discussion.

It is easy to mix fact and opinion; keep the Results and Discussion separate.

6. Avoid repetition.

- Do not repeat the Abstract in the Introduction or Discussion.

- Do not repeat the Introduction in the Discussion.

- In the text, do not repeat legends for figures, table titles, or the contents of the tables (such as values, means, or standard deviations). A paragraph full of numbers is not merely repetitious, it makes deadly reading. Using words to convey the meaning of the table keeps the message short and clear. Readers who need the precise data will turn to the table.

7 . Be concise; don't ramble. Short papers are more likely to be accepted than long ones. The length of the paper ought to be in proportion to the content of the information.

8. Try not to use the passive voice because it takes the reader longer to read and understand than the active voice.

9. Avoid constructions that force the reader to stop and re-read the sentence. When you find yourself using "respectively," you may recognize that you have a problem. Example: "The mean values for men and women were $x$ and $y$, respectively." Substitute: "The mean value for men was $x$, and for women, $y$." This version is unambiguous and permits the reader to continue forward.

10. Mention of race in a case history is usually superfluous and not warranted. However, the race or other ethnic designation of the patient should be given in the history if the topic is later mentioned in the Discussion. That is, race should be included if, and only if, it is worth discussing.

11. Do not use the phrase "in man." "Human" is the appropriate alternative; it can be used as an adjective or noun, is unambiguous, and does not evoke controversy. 


\section{More Advice}

1. Most editors dislike "and/or." Your meaning is usually conveyed by "or" alone. If it is important, you can add "or both" at the end of the sentence. ("Subarachnoid hemorrhage can cause headache, stiff neck, or both.")

2. "Parameter" is a popular word, but one that is frequently used erroneously and ambiguously; it is better to write exactly what you mean. You may think you are using "parameter" correctly, but you probably aren't (read the short essay on the subject in Neurology $1984 ; 34: 1591)$.

3. "CNS" should be used only if it refers to brain and spinal cord. It is not a synonym for "brain" or "cerebral."

4. "Deficit" may be used, if at all, only to describe neurologic signs and not symptoms. The precise meaning of "deficit" must be obvious from preceding information.

5. Automatic deletions-wasted words and phrases that should be deleted on sight:

prior history (all history is prior)

careful history and examination (we are all careful)

it is shown that

it is emphasized that

it is a fact that

it is known that

provided a means of

etc.

very

6. Some translations from medicalese:

We are accused of dehumanizing patients. Consider the following:

instead of
pediatric population
male infants
female infants
males
females
case

use

children

boys

girls

men or boys

women or girls

patient

\section{Sample substitute phraseology:}

$\begin{array}{ll}\text { instead of } & \text { use } \\ \text { appears to be } & \text { seems } \\ \text { as to whether } & \text { whether } \\ \text { in the absence of } & \text { without } \\ \text { higher in comparison to } & \text { more than } \\ \text { chose to use } & \text { used } \\ \text { control groups } & \text { controls } \\ \text { disease process } & \text { disease } \\ \text { was found to be } & \text { was } \\ \text { due to the fact that } & \text { because } \\ \text { greater number of } & \text { more than } \\ \text { in the event that } & \text { if } \\ \text { it is possible that } & \text { may } \\ \text { interval of time } & \text { interval } \\ \text { small number of } & \text { few } \\ \text { a number of } & \text { some } \\ \text { large number of } & \text { many } \\ \text { in order to } & \text { to } \\ \text { power } & \text { strength } \\ \text { 3-month period } & \text { 3 months } \\ \text { period of time } & \text { period } \\ \text { point in time } & \text { point } \\ \text { it is possible that } & \text { may have been } \\ \text { reported in the literature } & \text { reported } \\ \text { reduced by } \text { \%\% compared with } & \text { x\% lower than } \\ & \text { or x\% less than } \\ \text { serves the function of being } & \text { is } \\ \text { surgical intervention } & \text { surgery, operation } \\ \text { was variable } & \text { varied } \\ & \end{array}$

For complete discussion on this subject, we recommend the book by E.J. Huth, Medical Style \& Format, ISI Press, Philadelphia, PA, 1987. 


\title{
Neurology
}

\author{
Suggestions to authors \\ Robert B. Daroff, Lewis P. Rowland and Carol Scism \\ Neurology 1988;38;1657 \\ DOI 10.1212/WNL.38.10.1657
}

This information is current as of October 1,1988

\section{Updated Information \& \\ Services}

Permissions \& Licensing

Reprints including high resolution figures, can be found at: http://n.neurology.org/content/38/10/1657.citation.full

Information about reproducing this article in parts (figures,tables) or in its entirety can be found online at: http://www.neurology.org/about/about_the_journal\#permissio ns

Information about ordering reprints can be found online: http://n.neurology.org/subscribers/advertise

Neurology @ is the official journal of the American Academy of Neurology. Published continuously since 1951, it is now a weekly with 48 issues per year. Copyright (C) 1988 by Edgell

Communications, Inc.. All rights reserved. Print ISSN: 0028-3878. Online ISSN: 1526-632X.

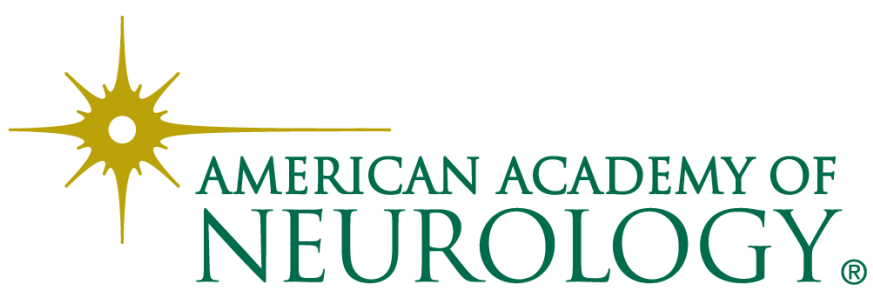

